\title{
Physicochemical quality of Murzuq groundwater Sabha, Libya
}

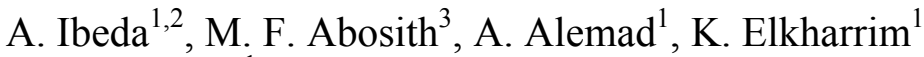 \\ \& D. Belghyti ${ }^{1}$ \\ ${ }^{1}$ Laboratory of Environment and Renewable Energy, Faculty of Sciences, \\ University Ibn Tofail, Kenitra, Morocco \\ ${ }^{2}$ Organization of Development, Sabha, Libya \\ ${ }^{3}$ Department of Environmental Sciences, Faculty of Engineering and \\ Technical Sciences, University of Sabha, Libya
}

\begin{abstract}
The objective of this study is to examine the physico-chemical quality of the Libyan Murzuq groundwater, to analyze the degree of its pollution and compare the quality standards for drinking water. The present investigation was carried out on water samples from 13 boreholes and water wells of Sabha, Libya localities.

Parameters studied were temperature, $\mathrm{pH}$, conductivity, TDS, salinity, Aluminum, Fluorine, Potassium, Sodium, Calcium, Magnesium, Iron, Copper, Manganese, Chloride, Sulfate, Silica, Nitrates, Nitrites, Ammonium, Ammonia, Nitrogen, Bicarbonate, Phosphate, Calcium Carbonate, hardness and alkalinity.

Analysis showed that the groundwater of Murzuq was within the limits of Libyan Standards. However, some element's analysis showed high concentrations (TDS, conductivity, Potassium, Sodium, Iron, Copper, Chloride, Manganese). Further analysis is needed to decide whether to limit the use of those waters for drinking.

Keywords: groundwater, physicochemical, quality, Murzuq basin, Sabha, Libya.
\end{abstract}

\section{Introduction}

Although Libya must be considered an arid country with an average rainfall of less than $100 \mathrm{~mm}$ over $93 \%$ of its land surface, there is important potential for groundwater development. In its report on water resources and management of 
shared aquifers in North Africa and the Sahel (UNESCO [1,2] and CEDARE [3]), counted in Libya four aquifers with respective surfaces $\left(\mathrm{Km}^{2}\right)$ and volumes $\left(\mathrm{Km}^{3}\right)$ :

* NAS-PNAS- Nubian and Post Nubian Sandstone Aquifer System (Libya, Egypt, Sudan, Chad) about $2199000 \mathrm{Km}^{2}$ and $540000 \mathrm{Km}^{3}$;

* SASS- North-West Sahara Aquifer System (Algeria, Libya, Tunisia) about $1000000 \mathrm{Km}^{2}$;

* Murzuk-Djado Basin (Libya, Niger) about $450000 \mathrm{Km}^{2}$ and $4800 \mathrm{Km}^{3}$;

* Aquifer system Djeffara (Libya, Tunisia) about $43000 \mathrm{Km}^{2}$.

The objective of this research on Murzuq-Sabha fossil aquifer is to study the evolution of the water chemical quality including water salinity, the analysis of the degree of its anthropogenic pollution and discuss the development of a regional strategy of control and monitoring for sustainable resources exploitation.

\section{Studied geographical area}

This exploration was conducted on water samples from 13 water wells of Sabha district (Figures 1-4, Table 1): Tourist hotel the mountain; Mehdia school's; Karda behind the building, Bilal Mosque Sokarah, Aboubaker Essadiq Sokarah Mosque; Moaskare Murzuq road; Manchiya Arbayine road, New Cemetery Sidi Hamed; Manchiya old Mosque; Sabha-Zirine road sample 1, sample 2, sample 1 " and sample 2". Sabha is located between lat $29^{\circ} 00^{\prime}$ to $29^{\circ} 40^{\prime} \mathrm{N}$ and long $12^{\circ} 35^{\prime}$ to $13^{\circ} 10^{\prime} \mathrm{E}$ and located very close to the northern extension of the upper reservoir (Figure 5), the saturated thickness of aquifers is limited to $100-120 \mathrm{~m}$.

The Murzuq basin is located on the southwestern of Libya (Figure 3) between Jabal Fezzan $\left(28^{\circ} \mathrm{N}\right)$, Jabal Qussa $\left(16^{\circ} \mathrm{E}\right)$, Chad-Niger (South) and Algeria (West). The wells penetrated from top to bottom, Quaternary deposits, the Nubian sandstone (Lower Cretaceous age) and upper part of the post Tassilian deposits, Jurassic (Touratine Formation) and Triassic (Zarzaitine Formation). The continental sandstones cover an area of approximately $125000 \mathrm{~km}^{2}$ in the Murzuq basin of southwestern Libya and adjacent areas (Algeria, Niger, Chad). The sandstone series overlies carboniferous marine sandstone and limestone, and is covered by late cretaceous and tertiary marine carbonates and recent sand dunes which make access difficult. Two main groundwater reservoirs are considered in the Murzuq basin (Figure 5):

* The lower groundwater reservoir includes the Siluro-Devonian and CambroOrdovician sandstones (Acacus sandstone, Tadrart sandstone). In this area we found Wadi ash Shati, Ghat, Wadi Tanezzuft, Al Awaynat, Wadi Aril and 135 killing wells flowing into Sabkhas.

* The upper groundwater reservoir includes the continental formations of Triassic, Jurassic and Lower Cretaceous usually known as the post-Tassilian and Nubian series (Figure 5). In this area we found Sabha, Tamanhant, Samnü-Azzighan, Wadi Ajal, Murzuq district, Wadi Irawan, Wadi Barjij. 


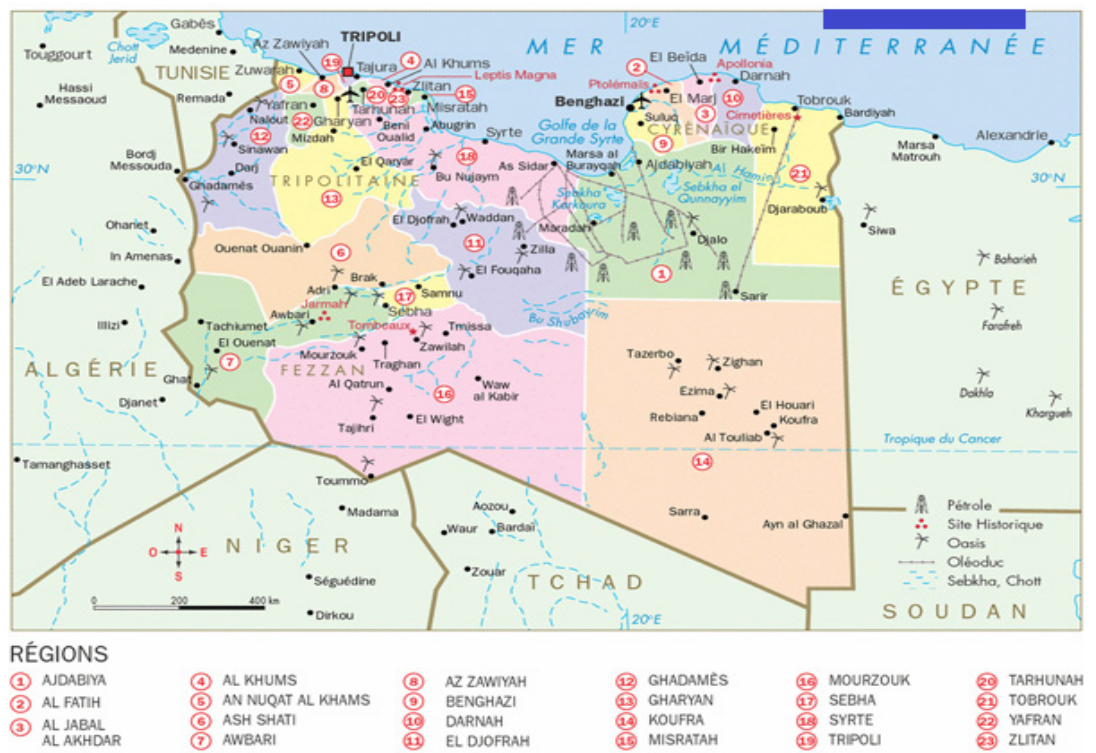

Figure 1: Geographical localization of Libyan districts and Murzuq (17).

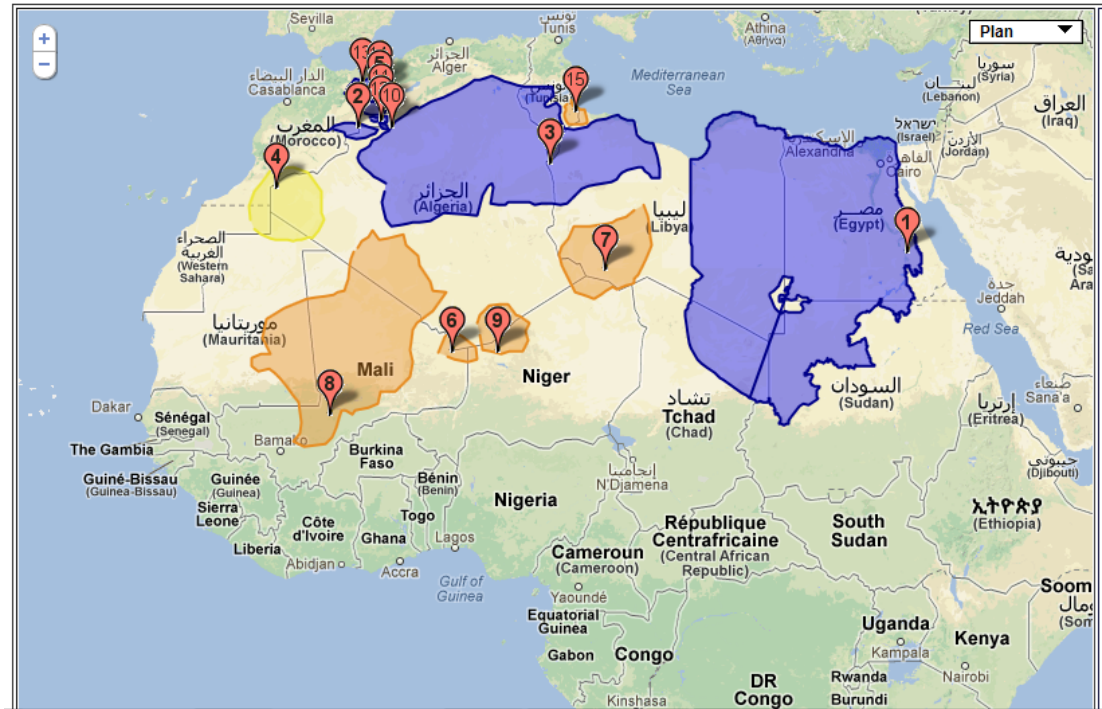

Figure 2: $\quad$ Aquifer system of Libya showing Murzuq aquifer (7) and other aquifers 1 to 15 . 


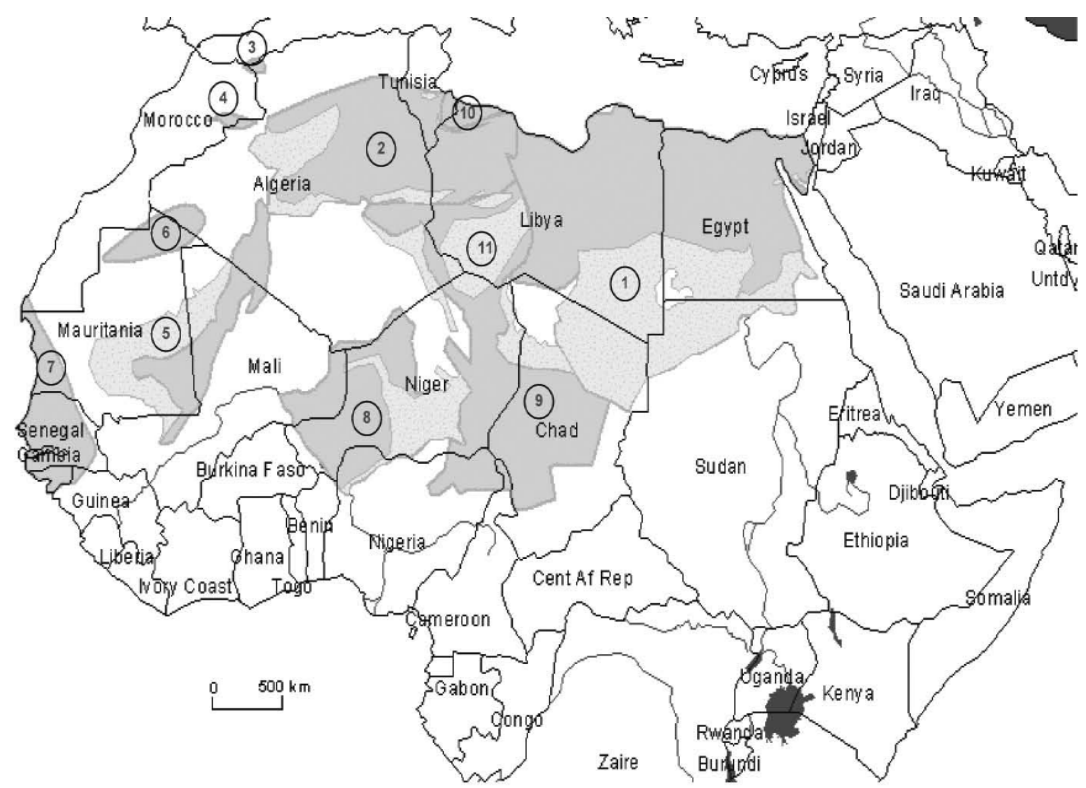

Figure 3: Hydrological resource of Libya.-1: Nubian sandstone system 2: Sahara and sahel aquifer system- 10: Djaddo- 11: Murzuq aquifer.

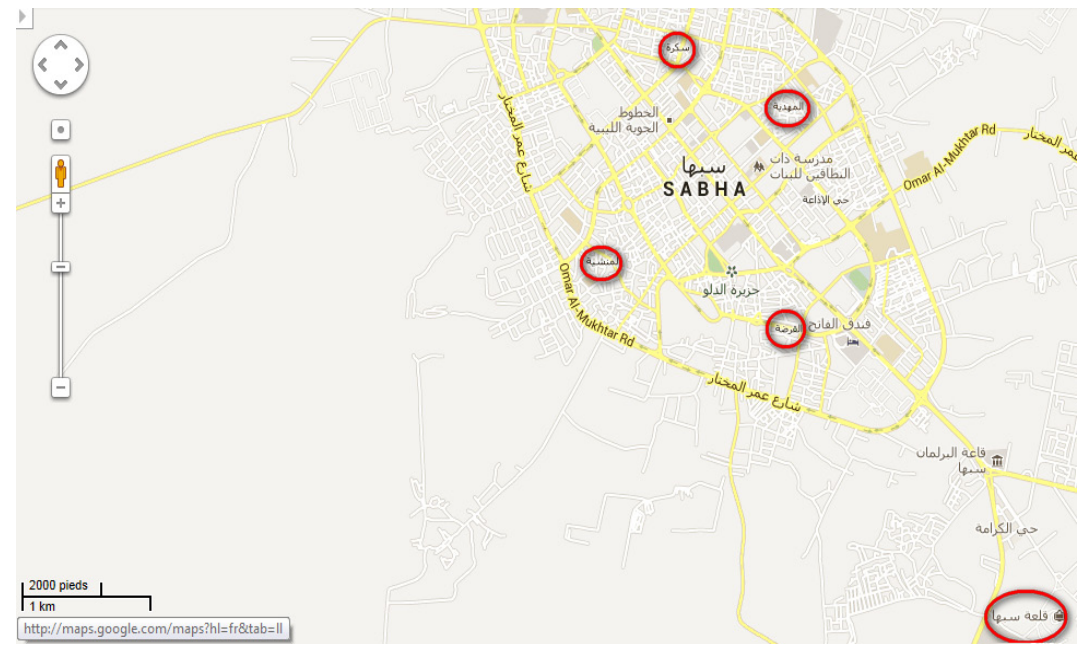

Figure 4: Water wells sampled from Sabha, Murzuq basin. 


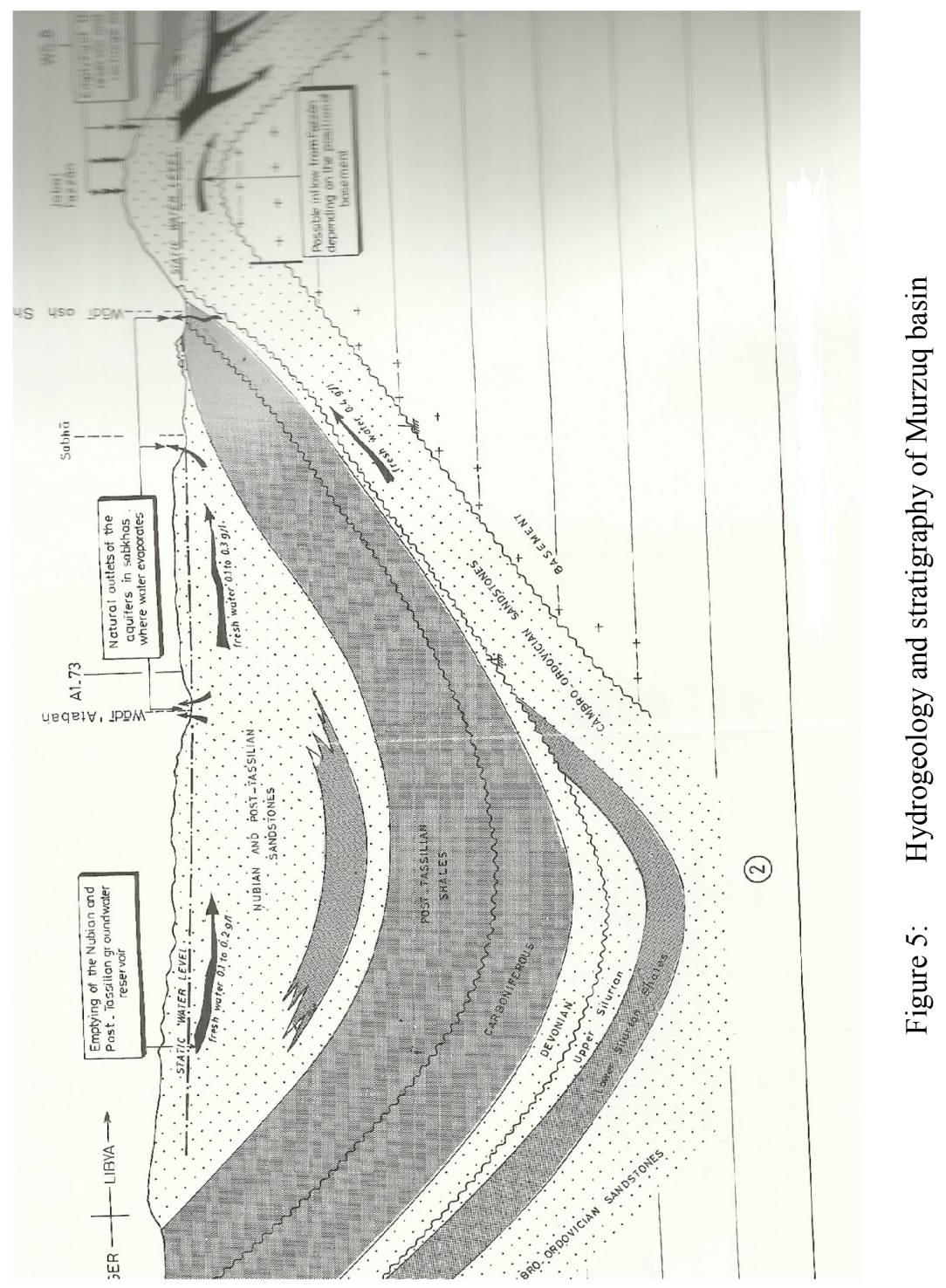


Table 1: $\quad$ Descriptive statistics of chemical analysis of Murzuq basin.

\begin{tabular}{|c|c|c|c|c|}
\hline Variable & Minimum & Maximum & Average & $\mathrm{SD}$ \\
\hline $\mathrm{T}^{\circ} \mathrm{C}$ & 26.300 & 26.500 & 26.400 & 0.041 \\
\hline $\mathrm{pH}$ & 6.700 & 8.900 & 7.535 & 0.752 \\
\hline $\mathrm{CE} \mathrm{ms/cm}$ & 198.000 & 4390.000 & 1152.000 & 1322.308 \\
\hline TDS mg/l & 240.000 & 2897.400 & 1752.200 & 762.075 \\
\hline $\mathrm{NaCl} \mathrm{mg} / \mathrm{l}$ & 28.000 & 28.000 & 28.000 & 0.000 \\
\hline $\mathrm{AL}+\mathrm{mg} / \mathrm{l}$ & 0.000 & 0.000 & 0.000 & 0.000 \\
\hline F- mg/l & 0.000 & 1.700 & 1.129 & 0.395 \\
\hline $\mathrm{K}+\mathrm{mg} / \mathrm{l}$ & 4.300 & 362.000 & 42.473 & 96.656 \\
\hline $\mathrm{Na}+\mathrm{mg} / \mathrm{l}$ & 6.000 & 284.000 & 174.400 & 66.219 \\
\hline $\mathrm{Ca}++\mathrm{mg} / \mathrm{l}$ & 8.640 & 104.000 & 65.888 & 23.041 \\
\hline $\mathrm{Mg}++\mathrm{mg} / \mathrm{l}$ & 14.400 & 93.280 & 40.157 & 23.841 \\
\hline $\mathrm{Fe}++\mathrm{mg} / \mathrm{l}$ & 0.020 & 2.100 & 0.749 & 0.752 \\
\hline $\mathrm{Cu}++\mathrm{mg} / \mathrm{l}$ & 0.090 & 12.000 & 1.694 & 3.186 \\
\hline $\mathrm{Mn}++\mathrm{mg} / \mathrm{l}$ & 0.000 & 0.600 & 0.262 & 0.190 \\
\hline Cl- mg/l & 16.970 & 568.000 & 349.874 & 117.241 \\
\hline $\mathrm{SO}_{4--} \mathrm{mg} / 1$ & 22.140 & 220.000 & 142.428 & 48.615 \\
\hline $\mathrm{SiO}_{2} \mathrm{mg} / 1$ & 15.200 & 16.140 & 15.755 & 0.233 \\
\hline $\mathrm{NO}_{3}-\mathrm{mg} / \mathrm{l}$ & 0.000 & 63.000 & 16.223 & 22.499 \\
\hline $\mathrm{NO}_{2}-\mathrm{mg} / \mathrm{l}$ & 0.033 & 0.066 & 0.041 & 0.008 \\
\hline $\mathrm{NH}_{4}+\mathrm{mg} / 1$ & 0.000 & 0.129 & 0.033 & 0.044 \\
\hline $\mathrm{NH}_{3}+\mathrm{mg} / 1$ & 0.061 & 0.122 & 0.085 & 0.015 \\
\hline $\mathrm{N}$ mg/l & 0.050 & 0.100 & 0.070 & 0.012 \\
\hline $\mathrm{HCO}_{3}-\mathrm{mg} / 1$ & 0.000 & 152.500 & 73.684 & 40.635 \\
\hline $\mathrm{CO}_{3}-\mathrm{mg} / \mathrm{l}$ & 0.000 & 0.000 & 0.000 & 0.000 \\
\hline $\mathrm{PO}_{4--} \mathrm{mg} / 1$ & 0.000 & 2.780 & 1.992 & 0.664 \\
\hline Hardness & 72.000 & 520.000 & 386.400 & 105.775 \\
\hline Alkalinity & 36.810 & 36.810 & 36.810 & 0.000 \\
\hline $\mathrm{CaCO}_{3} \mathrm{mg} / \mathrm{l}$ & 121.000 & 650.000 & 466.375 & 129.945 \\
\hline
\end{tabular}




\section{Methodology}

Studied parameters and methodology used are: temperature $\left(\mathrm{T}^{\circ} \mathrm{C}\right), \mathrm{pH}$, electric conductivity EC ( $\mu$ siemens/cm), TDS $(\mathrm{mg} / \mathrm{L})$, salinity $(\mathrm{mg} / \mathrm{L})$ with a multiparameter analyser and ion meters; Potassium and Sodium with a flame photometer; Calcium and Magnesium were measured by EDTA using a detector Murexid and Eriochrome Black T; Chlorides by Mohr's method (AFNOR T90014); total Phosphorus (TP) by colorimetric assay (molecular absorption spectrometry); total hardness, Calcium hardness, alkalinity, Bicarbonate and Carbonates are measured by volumetric hydrochloric acid $(0,05 \mathrm{~N})$ titration method (AFNOR T90 - 036) (Figure 6); determination of Kjeldahl nitrogen NTK by AFNOR method NF EN 25663; Nitrates and Sulfate measured by X-ray absorption UV.VIS.NIR.Spectrophotometer $(275,220 \mathrm{~nm}$ and $420 \mathrm{~nm})$ (Figure 7); atomic absorption spectrometry (Figure 7) for Manganese, Iron, Copper, Fluoride, Aluminum, Silica and Zinc.

\section{Results and discussion}

Fieldwork for this study was concentrated along the Sabha region. Data for other wells of the Murzuq basin were gathered from oil and gas test wells and an extensive literature search. Field determination of $\mathrm{pH}$, Electric conductivity, temperature, salinity, were carried out in all instances. Major and minor elements determinations in all cases were carried out on samples filtered through $0.45 \mu \mathrm{m}$ and acidified in the field.

Water aquifers tapped by the recent drilled wells always have nine ions predominate in the water taken from depth 120-200 $\mathrm{m}$ (Figures 4 and 5, Tables 1 and 2). They are $\mathrm{HCO}_{3}, \mathrm{Na}, \mathrm{Mg}, \mathrm{Ca}, \mathrm{Cl}, \mathrm{SO}_{4}, \mathrm{SiO}_{2}, \mathrm{~K}, \mathrm{NO}_{3}$. The comparative study of previous chemical analysis shows that the 13 wells are different and almost with higher (TDS, $\mathrm{Mg}, \mathrm{Na}, \mathrm{Ca}, \mathrm{SO} 4, \mathrm{Cl}$ ) than the water from Devonian and Cambro-Ordovician sandstone (Table 3) of Wadi ash Shati (Dubay [4]). However, there are no noticeable differences in chemical composition for $\mathrm{K}, \mathrm{Fe}$, $\mathrm{Mn}$ and $\mathrm{HCO}_{3}$.

We noted a high salt content with TDS usually ranging from 1458.6 to $2897.4 \mathrm{mg} / \mathrm{L}$ and rarely between 240 and $844.8 \mathrm{ppm}$ (Tables 1 and 4). The area located east of the line Murzuq-Awbari seems to have an upper salty aquifer and in the vicinity of the Sabkhas, the shallow aquifers may have very high TDS exceeding $5000 \mathrm{ppm}$ (Pallas [5]). It is noted that low values of the TDS from the water-table aquifer range from 75.7 to 126.3 to $176.7 \mathrm{ppm}$ in Al Hutiyah area Wadi Al Ajal (Sabha) (Table 4) and TDS increase with depth of the aquifer (Zaluski and Sadek [6]). The authors also noted that the TDS of water from Murzuq confined aquifer is much lower (1000-3000 ppm) than TDS of the shallow aquifers traditionally used through dug wells which have a much higher TDS, ranging from 1000 to $4000 \mathrm{ppm}$. The differences between the high TDS value $(2897 \mathrm{ppm})$ of the shallow aquifer and the very low value $(240 \mathrm{ppm})$ (Table 1) of deep aquifer, also confirm that the movement of water is upwards rather than downwards. 

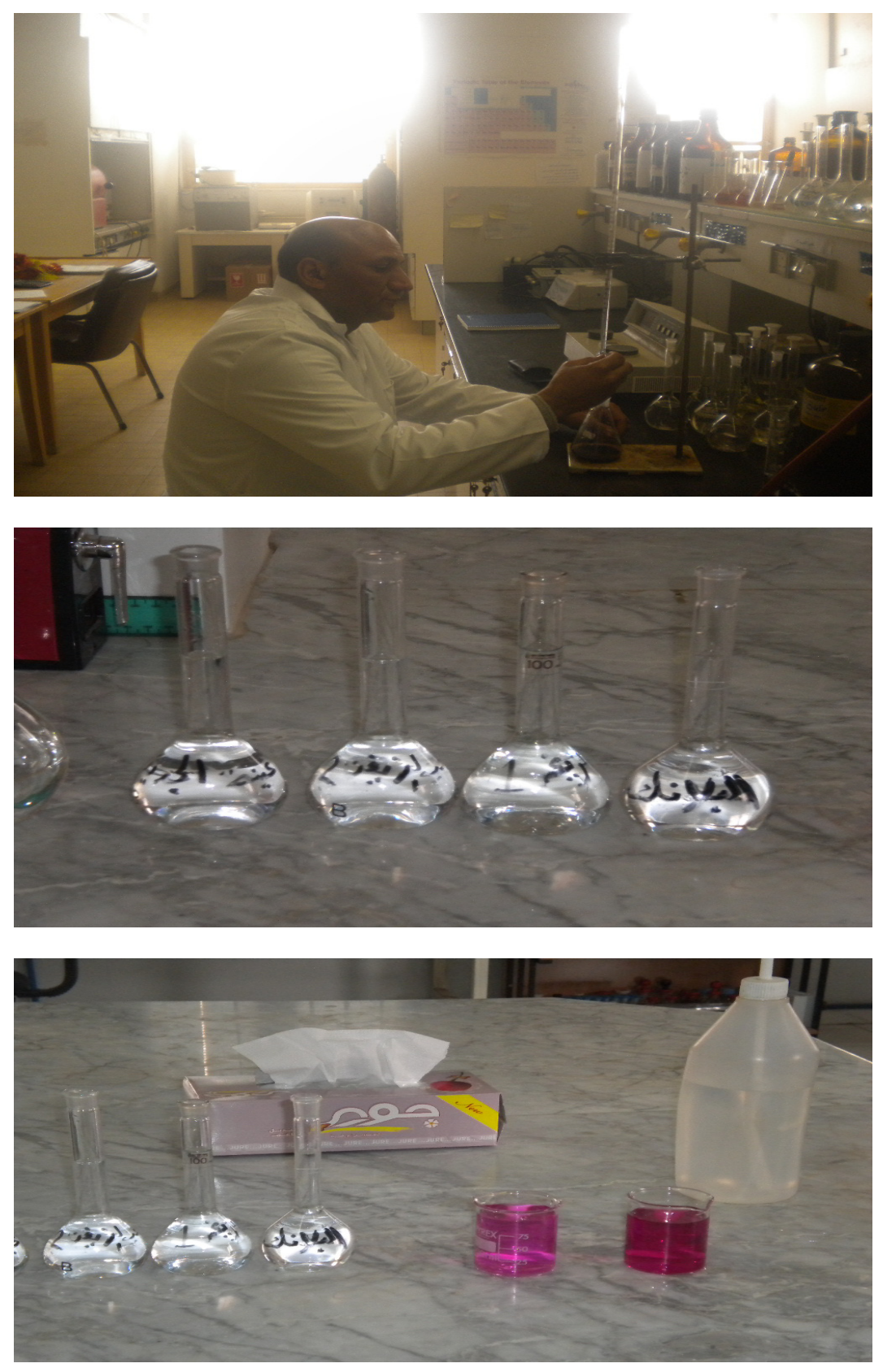

Figure 6: Titration unit for water analyses. 

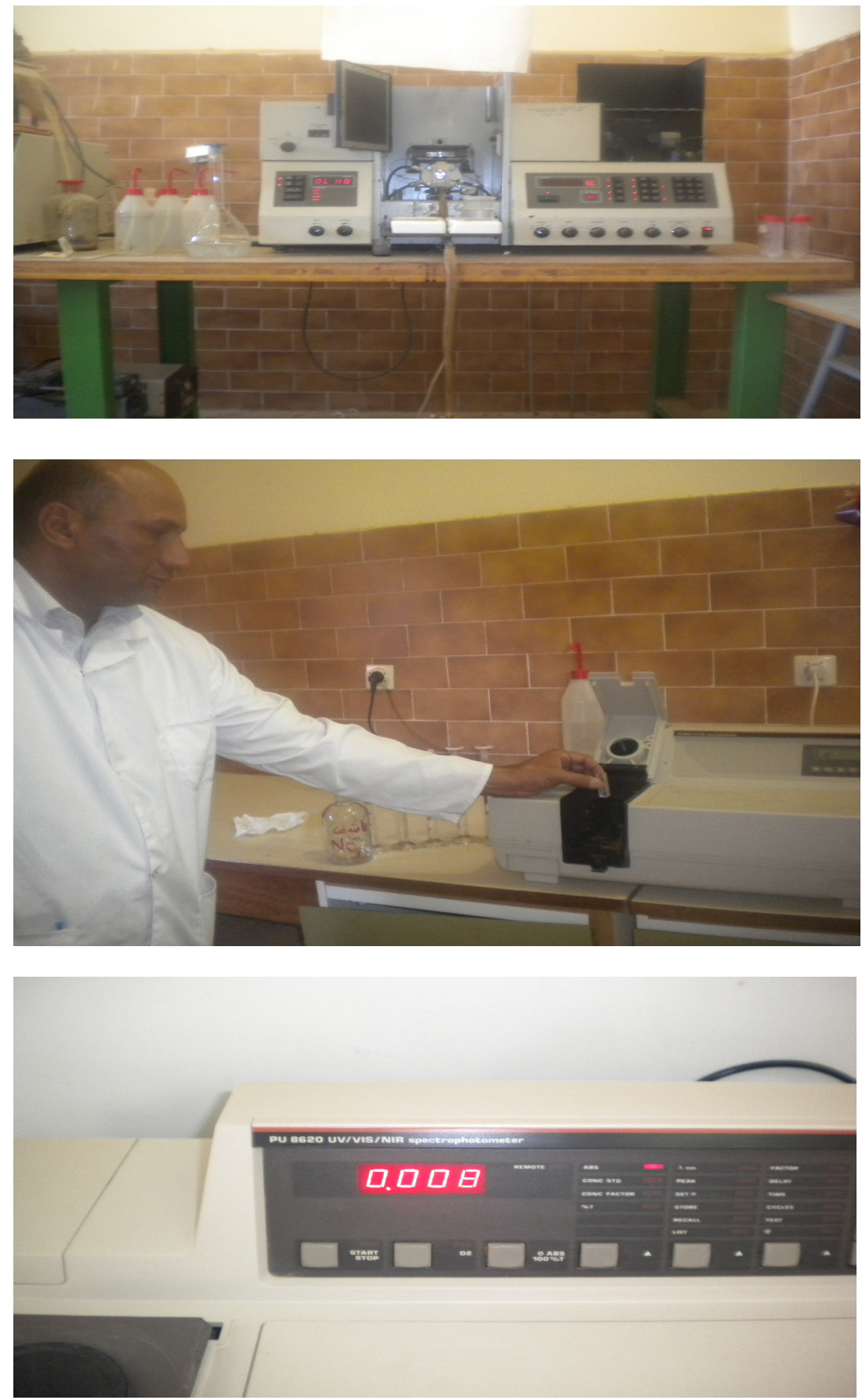

Figure 7: Atomic absorption and spectrophotometer UV-VIS-INR. 
In a lower reservoir, usually the water is very good chemical quality and TDS range from 300 to $500 \mathrm{ppm}$ in Wadi ash Shati and from 150 to 250 in Wadi Tenezzuft (Pallas [5]). However, water analysis in western Wadi ash Shati indicates salty water in the Northwestern part. Salinity increases towards West.

The principal component analysis (PCA) with statistical program (XLSTAT) (Figures 8 and 9) shows homogenous study stations with exception for mountain hotel and Zirine. Also the study revealed lower water pollution by nitrates in Manchiya (63mg/L) and Karda areas (48 mg/L) (Table 1). and its little mineralization by dangerous metals like Al Kufrah (Tables 5 and 6) such as Fluoride (1.7 ppm), Potassium (362 ppm), Sodium (284 ppm), Iron (2.1 ppm), Copper (0.8 ppm), Chloride (568 ppm) and Manganese $(0.6 \mathrm{ppm})$ whose are higher than the limits (Table 7) of WHO Guidelines [7,8] and Libyan Standards limits. $\mathrm{CO}_{2}$, nitrogen and other gases are also present. The gases might have

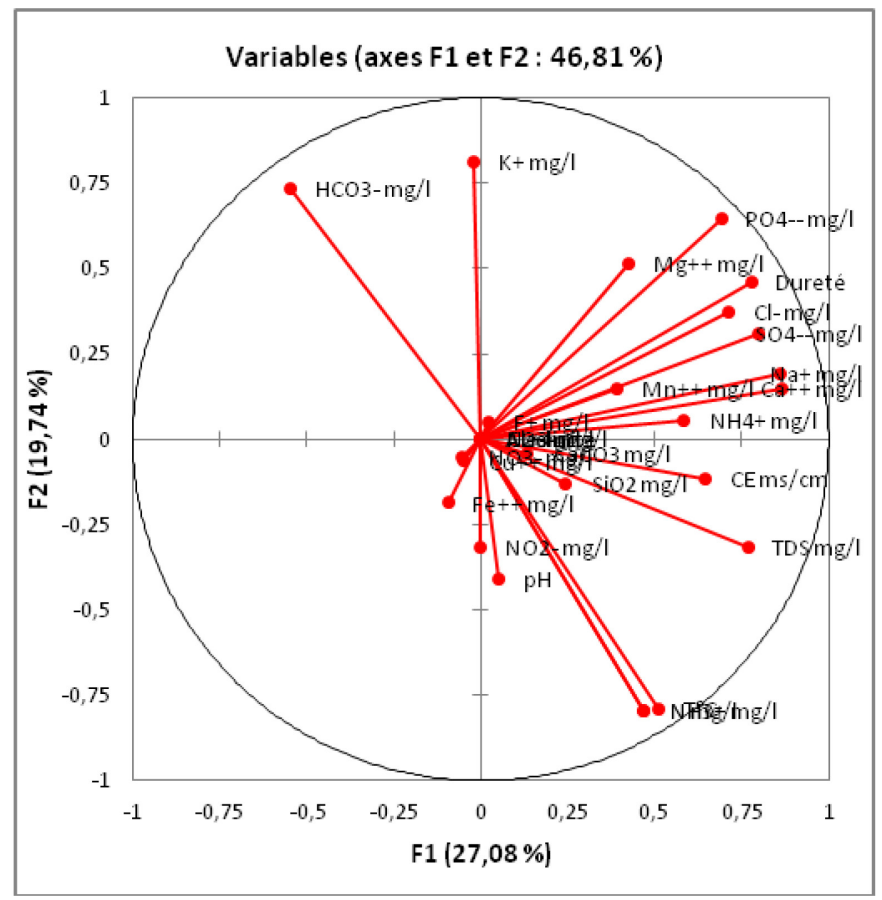

Figure 8: Factorial analysis (CFA) of physicochemical parameters (XLSTAT).

Table 2: $\quad$ Grading of aquifer in terms of salinity (Sinha [10]).

\begin{tabular}{|l|l|l|}
\hline Grade & Salinity as NaCl Equivalent $(\mathrm{ppm})$ & Type \\
\hline I & $0-2000$ & Fresh water \\
II & $2000-4000$ & Brackish-water \\
III & $4000-6000$ & Brackish-water to saline \\
IV & $>6000$ & Saline \\
\hline
\end{tabular}


originated from the decomposition of hydrocarbons. In fact, dead oil traces are very frequently found mainly in Devonian sandstones. The presence of shallow aquifers with a much higher salinity may constitute an important risk of deterioration in the water quality of the fresh aquifer in the case of vertical downward leakage due to the water extraction in the deeper aquifers.

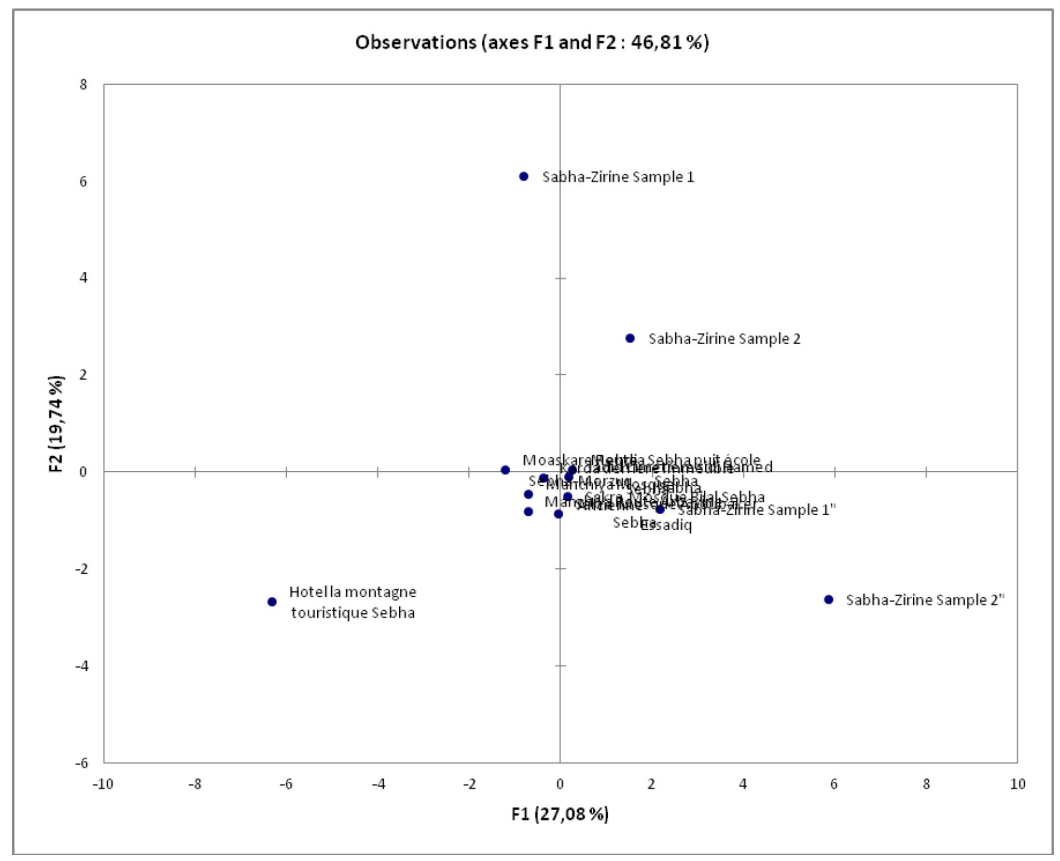

Figure 9: Factorial analysis (CFA) of water wells Sabha, Murzuq basin (XLSTAT).

Table 3: $\quad$ Groundwater in Wadi ash Shati Fezzan Dubay [4].

\begin{tabular}{|l|c|c|}
\hline & Devonian & Cambro-Ordovician \\
\hline $\mathrm{T}^{\circ} \mathrm{C}$ & 31 & 34.5 \\
\hline $\mathrm{pH}$ & 6.6 & 6.6 \\
\hline $\mathrm{EC} \mathrm{mhos} / \mathrm{cm}$ & 783 & 799 \\
\hline $\mathrm{TDS}(\mathrm{ppm})$ & 515 & 510 \\
\hline $\mathrm{Ca}(\mathrm{ppm})$ & 19.2 & 18.0 \\
\hline $\mathrm{Mg}(\mathrm{ppm})$ & 10.8 & 12.9 \\
\hline $\mathrm{Na}(\mathrm{ppm})$ & 122.8 & 155.6 \\
\hline $\mathrm{K}(\mathrm{ppm})$ & 22.3 & 25.8 \\
\hline $\mathrm{HCO}_{3}(\mathrm{ppm})$ & 176.9 & 155.6 \\
\hline $\mathrm{SO}_{4}(\mathrm{ppm})$ & 11.5 & 20.6 \\
\hline $\mathrm{Cl}_{(\mathrm{ppm})}$ & 166.3 & 159.5 \\
\hline $\mathrm{Fe}(\mathrm{ppm})$ & 2.6 & 2.1 \\
\hline $\mathrm{Mn}(\mathrm{ppm})$ & 0.25 & 0.5 \\
\hline $\mathrm{CO}_{2}(\mathrm{ppm})$ & 72 & 80 \\
\hline
\end{tabular}


Table 4: $\quad$ Hydrochemical of Wadi Al Ajal Sabha (Zaluski and Sadek [6]).

\begin{tabular}{|c|c|c|c|c|c|}
\hline Area & $\begin{array}{c}\text { Parameter } \\
\text { mequ/L }\end{array}$ & Aquifer2 & Aquifer3 & Aquifer4 & Aquifer5 \\
\hline \multirow{9}{*}{$\begin{array}{c}\text { Ad Disah } \\
\text { Al Hatiyah } \\
\text { Jarmah } \\
\text { Graya } \\
\text { Rogheba }\end{array}$} & $\mathrm{Ca}++$ & 24 & $28-35$ & $25-30$ & $4-32$ \\
\hline & $\mathrm{Mg}++$ & 30 & $24-40$ & $206-27$ & 4 \\
\hline & $\mathrm{Na}+$ & 46 & $25-48$ & $43-55$ & $60-86$ \\
\hline & $\mathrm{K}+$ & ---- & $12-15$ & $12-15$ & $4-6$ \\
\hline & HCO3- & 46 & $25-44$ & $29-44$ & $53-54$ \\
\hline & Cl- & 28 & $21-34$ & $29-38$ & $24-25$ \\
\hline & SO4- & 12 & $21-33$ & $13-40$ & 17 \\
\hline & NO3- & 13 & 8-14 & $2-4$ & 5 \\
\hline & Total ppm & 75,5 & $75,0-121,0$ & $96,0-144,2$ & $176,7-184,9$ \\
\hline
\end{tabular}

Table 5: $\quad$ Chemical analysis of Al Kufra basin (El Ramly [13]).

\begin{tabular}{|l|l|l|}
\hline Source & East Lake & West Lake \\
\hline $\mathrm{pH}$ & 7.00 & 7.50 \\
$\mathrm{EC}($ micromhos $)$ & 172500 & 145000 \\
TDS (ppm) & 219800 & 138200 \\
$\mathrm{Ca}(\mathrm{ppm})$ & 800 & 881 \\
$\mathrm{Mg}(\mathrm{ppm})$ & 4464 & 4272 \\
$\mathrm{Na}(\mathrm{ppm})$ & 73692 & 41400 \\
$\mathrm{~K}(\mathrm{ppm})$ & 2925 & 3120 \\
$\mathrm{HCO}_{3}(\mathrm{ppm})$ & 293 & 565 \\
$\mathrm{Cl}(\mathrm{ppm})$ & 112044 & 65320 \\
$\mathrm{SO}_{4}(\mathrm{ppm})$ & 25000 & 20557 \\
$\mathrm{SiO}_{2}(\mathrm{ppm})$ & 15 & 25 \\
$\mathrm{Hardness} \mathrm{CaCO}_{3}(\mathrm{ppm})$ & 20600 & 20000 \\
\hline
\end{tabular}

Table 6: Trace element determination for Al Kufrah (Maksimovic and Eskangi [14]).

\begin{tabular}{|l|l|l|l|}
\hline Element & Amount & Element & Amount \\
\hline $\mathrm{B}$ & 7.497 & $\mathrm{Ag}$ & nil \\
\hline $\mathrm{Ba}$ & 2.934 & $\mathrm{Be}$ & nil \\
\hline $\mathrm{Cr}$ & 0.326 & $\mathrm{Cd}$ & nil \\
\hline $\mathrm{Cu}$ & 0.554 & $\mathrm{Co}$ & nil \\
\hline $\mathrm{Mn}$ & 0.6845 & $\mathrm{Ga}$ & nil \\
\hline $\mathrm{Mo}$ & 0.326 & $\mathrm{Sc}$ & nil \\
\hline $\mathrm{Ni}$ & 0.236 & $\mathrm{Sn}$ & nil \\
\hline $\mathrm{Pb}$ & 0.880 & $\mathrm{Y}$ & nil \\
\hline $\mathrm{Sr}$ & 35.855 & $\mathrm{~V}$ & 2.608 \\
\hline $\mathrm{Ti}$ & 3.585 & $\mathrm{Zn}$ & 4.563 \\
\hline
\end{tabular}

Table 7: $\quad$ Trace elements data for the water samples in $\mathrm{mg} / \mathrm{l}$ (WHO $[7,8])$.

\begin{tabular}{|c|c|c|c|c|c|c|c|c|}
\hline $\mathbf{C d}$ & $\mathbf{C r}$ & $\mathbf{C u}$ & $\mathbf{F}$ & $\mathbf{F e}$ & $\mathbf{P b}$ & $\mathbf{N i}$ & $\mathbf{M n}$ & $\mathbf{Z n}$ \\
\hline 0.003 & 0.05 & $1-2$ & $0.5-1.5$ & 0.3 & 0.01 & 0.02 & $0.1-0.5$ & 3.0 \\
\hline TDS & $\mathbf{C a}$ & $\mathbf{M g}$ & $\mathbf{N a}$ & $\mathbf{H C O}_{3}$ & $\mathbf{C l}$ & $\mathbf{S O}_{4}$ & $\mathbf{N O}_{3}$ & $\mathbf{P O}_{4}$ \\
\hline 1000 & 200 & ---- & 200 & ---- & 250 & 400 & 50 & ---- \\
\hline
\end{tabular}


Slight increases of salinity have already been noticed in some wells of the Awbari project and might be connected with contamination of the fresh aquifer tapped in the wells by a shallow saline aquifer around sabkhas.

The operation leads to an activation of the vertical communication systems interconnected. Also we noted a decline in piezometric level connected with the operation of agriculture project. 110-120 m below ground surface after 50 years of drilling. The available piezometric data suggests a groundwater flow from south to north and discharge through the sabkhas along the depressions: Wadi al Ajal, Wadi Murzuq, Wadi ash Sharqiyah, Wadi Alabah, Lakes in Awbari sand sea. The water was stored in the Murzuq basin thousands of years ago. Klitzsch et al. [9] estimate the age of water to several thousand years old. The water resources of Sabha should, accordingly, be regarded as unrechargeable. The recharge of any aquifer from present occasional rainfall is very unlikely in the region. Precipitation is very low and evaporation very high. No recharge from ground level is likely since the piezometric surface of the confined aquifers generally rise with depth, thus excluding the possibility of downwards percolation.

\section{Conclusion}

A summary of the characteristic features of the different Murzuq aquifers is given as fallow by Sinha and Pandey [11]. The most extensive and good quality aquifer is in the Nubian sandstone. Its thickness ranges from 150 to $500 \mathrm{~m}$. It is freshwater bearing with salinity ranging from $200-850 \mathrm{ppm} \mathrm{NaCl}$ equivalent. All the shallow wells, for domestic as well as agricultural purposes, draw water from this aquifer. Jurassic and Cambro-Ordovician aquifers are considered to be the second best after the Nubian. Jurassic aquifers are sand beds with occasional intercalations of clays. They are freshwater-bearing with salinity ranging from 200-1300 ppm NaCl equivalent. This bed is about $800 \mathrm{~m}$ thick in the south (Al Qatrun). The CambroOrdovician aquifer is prominent in the north. Its thickness is about $500 \mathrm{~m}$ in the Sabha region. It is mainly a sandstone bed with occasional shaly layers in its upper parts. Average salinity is $1200 \mathrm{ppm} \mathrm{NaCl}$ equivalent.

The Carboniferous aquifers are saline, 7000-10000 ppm $\mathrm{NaCl}$ equivalent. The deterioration in water quality is due mainly to the presence of gypsiferous beds and important proportion of evaporits.

The aqueous trace element levels can be related to lithofacies and are primarily controlled by the reaction of groundwater with the carbonates, sulfates or others minerals present (calcite, aragonite, fluorite, fluorapatite, barite, dolomite, strontianite, celestite). Aragonite and Mg-calcite for example will dissolve incongruently to precipitate a low $\mathrm{Mg}$-calcite and the groundwater will become enriched in the exsolved ions including $\mathrm{Ca}^{++}, \mathrm{F}-, \mathrm{Sr}^{2+}$.

Also strontium, boron, bromide, fluoride, lithium (Edmunds [12]) and their saturation index and coefficients distribution $(\mathrm{Sr} / \mathrm{Ca}, \mathrm{Sr} / \mathrm{Cl}, \mathrm{Mg} / \mathrm{Ca}$,) may be used as natural tracers together with other geochemical and hydrogeological information in ground water investigation; i.e., to distinguish marine-derived from no-marinederived groundwater.

More hydrogeological, geochemical and hydobiological studies are need throughout the Murzuq basin to understand the freshwater-salt-water-oil relationship, 
to determine the water quality typology, to relate it to hydrogeochemical units and to establish the suitability of the water for domestic, agricultural and industrial use.

\section{References}

[1] UNESCO, Ressources en eaux et gestion des aquifères transfrontaliers de l'Afrique du nord et du sahel: Paris, 2006.

[2] UNESCO, Vers une Gestion Concertée des Systèmes Aquifères Transfrontaliers. Constat Préliminaire Partie I: Académie de l'Eau, BRGM, OIEau, UNESCO, Paris, Août 2011.

[3] CEDARE, National status reports of Egypt, Sudan and Libya on the development and utilization of the Nubian sandstone aquifer. CEDAREIFAD. Reports 1994, Cairo, 99, 100 and 41 pages respectively.

[4] Dubay, L., Groundwater in Wadi ash Shati, Fazzan - A case history of resource development. Proc of the geology of Libya. Second Symposium on the Geology. Libya, held at Tripoli, September 16-21, 1978, eds Academic Press Inc: New York, pp. 611-627, 1980.

[5] Pallas, P., Water Resources of the Socialist People's Libyan Arab Jamahiriya - Proc of the geology of Libya. Second Symposium on the Geology. Libya, held at Tripoli, September 16-21, 1978, eds Academic Press Inc: New York, pp. 539-594, 1980.

[6] Zaluski, M. and Sadek, K.E., Hydrogeological of Mesozoic aquifers in Western part of Wadi al Ajal. Proc of the geology of Libya. Second Symposium on the Geology. Libya, held at Tripoli, September 16-21, 1978, eds Academic Press Inc: New York, pp. 635-642, 1980.

[7] World Health Organization (WHO), (eds). Guideline for Drinking Water Quality, Health Criteria and Other Supporting Information: 2nd Edition, Vol.2, Geneva, pp. 940-949, 2004.

[8] World Health Organization (WHO), (eds). Guideline for Drinking Water Quality, Health Criteria and Other Supporting Information: 2nd Edition, Vol.2, Geneva, pp. 940-949, 2004.

[9] Klitzsch, E., Sontag, C., Weitroffer, K. and El Shazly, E.M. Groundwasser der Zentralsahara: Fossil vorrate. Geol. Rundsch., 65, pp. 264-287, 1976.

[10] Sinha, S.C., On the application of geological logging in the assessment of groundwater potential in Al Hamada al Hamra basin. Proc of the geology of Libya. Second Symposium on the Geology. Libya, held at Tripoli, September 16-21, 1978, eds Academic Press Inc: New York, pp. 643-658, 1980.

[11] Sinha, S.C. and Pandey, S.M., Hydrogeological studies in part of Murzuq basin using geological logs. Proc of the geology of Libya. Second Symposium on the Geology. Libya, held at Tripoli, September 16-21, 1978, eds Academic Press Inc New York. pp. 629-633, 1980.

[12] Edmunds, W.M., The hydrogeochemical characterization of ground waters in the Sirt basin, using Strontium and other Elements. Proc of the geology of Libya. Second Symposium on the Geology. Libya, held at Tripoli, 
September 16-21, 1978, eds Academic Press Inc: New York, pp. 703-714, 1980.

[13] El Ramly, I.M., Al Kufrah Pleistocene Lake- Its evolution and role in present-day land reclamation. Proc of the geology of Libya. Second Symposium on the Geology, Libya, held at Tripoli, September 16-21, 1978, eds Academic Press Inc: New York, pp. 659-670, 1980.

[14] Maksimovic, A. and Eskangi, E.M., Trace elements in groundwater of the Kufrah basin (Libya Arab, Republic). Bull. Acad. Serbe Sci., cl. Sci. Math. Nat., 61, pp. 1-19, 1978. 